Ankara Üniversitesi Türk İnkılâp Tarihi Enstitüsü Atatürk Yolu Dergisi

S 29-30, Mayıs-Kasım 2002, s. 143-158

\title{
II. Dünya Savaşı Yıllarında Laiklik Uygulamaları: Değişimin İk İşaretleri
}

\author{
Yrd. Doç. Dr. Esma TORUN*
}

ÖZET

Atatürk'ün ölümü Türk tarihi açısından önemli bir dönüm noktasıdır. Onun ölümünden hemen sonra başlayan II.Dünya Savaşı ise, Türkiye'nin siyasi, sosyal ve kültürel yaşamında önemli değişimlere neden olmuştur. Gerek savaş yıllarında yaşanan gelişmeler gerekse savaşın sonucunda ortaya çıkan koşullar Türk devriminin de yönünü belirlemiştir. Bu devrimler içinde laiklik ilkesi ve uygulamaları, Atatürk'ün ölümüyle birlikte değişim sürecine girmiştir. Değişim sürecinde en büyük etkiyi CHP ve devlet yönetimindeki kadro değişimi önemli rol oynamıştır. Atatürk döneminde yer altına gizlenmek zorunda kalan devrim karşıtları, onun ölümüyle birlikte kendilerini ortaya koymaya başlamışlardır. Gerek devrim karşıtlarının faaliyetlerinin artması gerekse vatandaşların ibadetlerine yardımcı olmak üzere kurulan Diyanet İsleri Başkanlığının daha etkin girişimleri, savaş yılları içinde artış göstermiştir. Ancak, en büyük ve olumsuz sonuçları, savaştan sonra gerçekleşen çok partili hayatla birlikte ortaya konulacaktır. Bununla birlikte savaş yılları, toplumsal muhalefetin güçlendirmesinin yanı sıra devrim karşıtlarının da parti ve devlet yönetiminde kadrolaşmasını da beraberinde getirmiştir. Savaş yılları büyük ölçüde laiklik ilkesi ve uygulamalarında değişimin ilk işaretlerinin verilmeye başlandığı yıllar olmuştur.

Anahtar Kelimeler: CHP, Laiklik, Diyanet İşleri Başkanlığı

\section{ABSTRACT}

Atatürk's death is a turning point for Turkish history. The Second World War which broke out just after his death caused significant changes in political, social and cultural life of Turkey. Both the developments experienced during the years of war and the conditions emerged as a result of the war have determined the fate of Turkish revolutions. Among those the principle of Secularism and its applications

\footnotetext{
• Kocaeli Üniversitesi, Atatürk İlkeleri ve İnkılap Tarihi Bölümü.
} 
entered into a period of change following the death of Atatürk. Changing some positions in the Republican People's Party and in the government played the most important role in this change period. Those revolution opponents who had had to hide underground during Atatürk's government period started to appear after he's death. Both the increase of the activities of the revolution opponents and more effective initiatives of the Division of Religious Affairs which had been established to assist the citizens with their religious obligations increased considerably during the war years. However, the most important and adverse results were to be seen during the multi-party life introduced after the war. In addition to this, the experience of war would both strengthen the social opposition and be accompanied by politically oriented assignments of the revolution opponents to the positions in the government and party had affected all political system. Secularism applications had started to change in war period. I think that first sing of changes was given in this period and this prepared ground for first concessions.

Keywords: Republican People's Party, Secularism, Division of Religious Affairs

II. Dünya Savaşı yıllarında Türkiye'nin iç ve dış politikasıyla ilgili bir çok çalışma yapılmış olmasına rağmen, dönemin laiklik uygulamaları bugüne kadar yapılan çalışmalara pek konu olmamış ve bu dönemde Atatürk dönemindeki uygulamaların aynen devam ettirildiği genel olarak kabul görmüştür. Bununla birlikte bu dönemde katı laiklik uygulamalar söz konusu olduğu ileri sürülmektedir. Ancak tüm bunlara rağmen bu görüşler bilimsel bir temele oturtularak araştırılmasının söz konusu edilmediği görülebilmektedir. Bu nedenle araştırmalarımız sonucu elde ettiğimiz belgeler doğrultusunda bu dönemin laiklik uygulamalarını inceleme ve gözden geçirme gereği duyduk. Amacımız, Atatürk'ün ölümüyle başlayan yeni dönemin laiklikle ilgili yaklaşım ve uygulamalarındaki değişikliği ortaya koyarak, çok partili hayata geçiş sürecindeki değişimlere etkisini saptayabilmektir.

Tarihin derinliklerine bakıldığında, liderlerin ölümü toplumlar için yeni bir sürecin başlangıcına işaret etmektedir. Bu süreç çoğu kez bir çok sorun ve karışıklığı beraberinde getirmiştir. Toplumu arkasına alan ve değişimin öncülüğünü üstlenen liderlerin ölümü, siyasal yaşamda bir boşluğun oluşması nedeniyle iç savaş da dahil olmak üzere pek çok karışıklığa yol açabilmektedir. Ancak her insan gibi liderlerin ölümü de kaçınılmazdır. Önemli olan ondan sonra ülke yönetimini ele alacak kimselerin nasıl bir tutum sergileyeceğidir. Toplumların kaderi de bu süreçten büyük ölçüde etkilenecektir. Türk ulusunun büyük önderi Mustafa Kemal Atatürk’ün ölümü de Türkiye Cumhuriyeti'nin geleceğinin yönlendirilmesinde etkili bir unsur olarak karşımıza çıkmaktadır. 
Ulusal Bağımsızlık Savaşı'nın ilk yıllarından itibaren başlayan devrim süreci içinde, laiklik ilkesi ve uygulamaları önemli bir yer tutmaktadır. Ulusal egemenliğin zorunlu sonucu olan saltanatın ve hilafetin kaldırılmasıyla, cumhuriyetin ilanıyla başlayan laikleşme süreci, eğitimin laik temeller üzerine kurulmasıyla, dilin dinsel köklerinden kurtarılmasıyla, kadın-erkek eşitliğinin sağlanmasıyla, modern hukuk sisteminin benimsenmesiyle ve ibadetin Türkçeleştirilmesiyle birlikte laiklik, siyasal, sosyal ve kültürel yapıya bütünüyle yerleştirilmeye çalışılmıştır. Son olarak laiklik ilkesinin diğer ilkeleriyle birlikte devletin temel nitelikleri olarak anayasaya konulmasıyla laiklik ilkesinin tamamlandığı düşünülmüştür. Artık geriye dönüşün veya ödün verilmesinin söz konusu olmayacağ sanılmaktadır. Atatürk büyük bir dönüşümün öncüsü olmuştur; fakat yüzyıllardan beri devam eden alışkanlıkların, inançların ve düşüncelerin değişebilmesi için önemli bir sürece ihtiyaç duyulmaktadır. İşte bu noktada liderin ölümünden sonra yönetimi devralacak siyasi kadroların tutumu, Türk Devrimi'nin ve ilkelerinin geleceğini yönlendirmede en etkili unsur olacaktır.

Ulusal Bağımsızlık Savaşı yıllarından itibaren ulusun önderliğini üstlenen ve Türk Devrimi'nin gerçekleştirilmesinde en önemli rolü oynayan Atatürk, 10 Kasım 1938'de hayata gözlerini yummuştur. Atatürk'ün ölümünden sonra yerine kimin geçeceği konusunu, onun hastalığının ağırlaştı̆̆ 1 günlerde önemli bir tartışma konusu olmuştur. Ancak, Ulu önderin ölümünden hemen sonra "ikinci adam" olarak anılan ve Atatürk'ün döneminin en uzun süre başbakanlığını yürütmüş olan İsmet İnönü, Atatürk'ün son yıllarında siyasi yaşamdan uzaklaştırılmış olmasına rağmen, TBMM'deki milletvekillerinin tamamına yakınının oyunu alarak cumhurbaşkanı seçilmiştir. Yeni bir dünya savaşının rüzgarlarının hızla esmeye başladığı bir dönemde İnönü'nün herhangi bir karışıklık çıkmadan cumhurbaşkanı seçilmesi, toplumda bir rahatlama süreci yaşanmasına neden olmuştur.

İnönü cumhurbaşkanı seçildikten sonra TBMM'de yaptığı ilk konuşmada, Atatürk'e olan sevgisini bağlılığını dile getirerek, çağdaşlaşma yolunda devam edileceğini ve devrimlere bağlı kalacağını ifade etmiştir ${ }^{1}$. Onun bu konuşmasıyla ilk bakışta, Atatürk'ün ölmesine rağmen, izleyecekleri yolda bir değişmenin söz konusu olmayacağı göze çarpmaktadır. Oysa hemen sonrasında CHP kadroları ve devlet yönetimde yaşanan değişimler, yeni bir dönemin başlangıcına işaret etmektedir.

İnönü, cumhurbaşkanlığının ilk yıllarından itibaren kadro değişimini uygulamaya koymuştur. Özellikle devrimlere ve Atatürk'e muhalif olanların yeniden partiye ve devlet yönetimlerine katılımının sağlanması ve

' Şerafettin Turan, İsmet İnönü Yaşamı, Dönemi ve Kişiliği, Ankara, Kültür Bakanlığı Yay., 2000, s.130-131. 
muhaliflerle uzlaşma politikasını izlemesi ${ }^{2}$, devrimlerin sona erdiği söylentilerinin güçlenmesinde etkili olmuştur. Bunun yanı sıra devrimleri başından beri benimsemeyen ve karşı olan çevrelerde, devrimlerde gevşeme olacağı ve devrim uygulamalarında vazgeçileceği ümidi doğurmuştur. Bu noktada da en çok üzerinde durulan laiklik ilkesi ve uygulamaları olmuştur.

1939'da toplanan CHP'nin V. Büyük Kurultayı, yeni dönemin ilk işaretlerini vermesi açısından önemlidir. Dil Devrimi'ne uygun olarak 1935 'te hazırlanan program yerine bu kurultayda yeni hazırlanan program, Arapça ve Farsça kelimelerle dili eski haline getirilmiştir. Kurultayda bu değişikliğin eleştirilmesi üzerine, programın halk diliyle ve dildeki çalışmalar göz önüne tutularak hazırlandığı ileri sürülmüştür ${ }^{3}$. Oysa bu değişim kısa süreli de olsa dil devriminden geri dönüşün ilk işaretidir.

\section{Din Ĕ̈itimi}

Dil Devrimi'nde görülen bu ilk geri dönüş hareketi diğer devrimlere başlangıçta aynı şekilde yansıtılmamıştır. İnönü döneminin laiklikle ilgili uygulamalarına baktığımızda, ilk olarak karşımıza köy ilkokullarından din derslerinin kaldırılması çıkmaktadır. 1927 yılında bütün okulların müfredat programından din dersleri çıkarılmış olmasına rağmen, 1939 yılına kadar köy ilkokullarında haftada bir saat olmak üzere okutulmaya devam edilmiştir. Eğitim Bakanlığı, laik bir ülkenin okullarında din dersleri vermenin anayasaya aykırı olacağını savunmasına rağmen, boş inançlardan arınmış bir dinin köy ilkokullarında okutulmasında sakınca görmemiştir ${ }^{4}$. Ancak 1939'a gelindiğinde devrim karşıtı olan kesimlerin beklentilerinin aksine olarak köy okullarından da din eğitimi kaldırılmıştır' ${ }^{5}$. Laikliğin gereği olarak görülen bu uygulamayla din dersleri tüm okulların müfredat programından kaldırılarak, Atatürk'ün laiklik anlayışını tamamlayıcı nitelikte bir uygulama gerçekleştirilmiştir.

Bu ilk uygulama laikliğin, ödünsüz hatta bir önceki dönemi tamamlama amacı taşıyan bir şekilde uygulanacağı izlenimi doğuruyordu. Ancak köy okullarından din eğitimin kaldırılmasından kısa bir süre sonra din eğitimi sorunu ilk kez meclis gündemine taşınması beklentilerin bu yönde olmayabileceğini gösteriyordu. 3 Haziran 1942'de köy okullarının

${ }^{2}$ Ayrıntılı bilgi için bkz, Cemil Koçak, Türkiye'de Millî Şef Dönemi, C.II, İstanbul, İletişim Yay., 1996, s.90-115; Rauf Orbay, Cehennem Değirmeni Siyasi Hatıralarım, C.II, İstanbul, Emre Yay., 1993, s.242-250; Esma Torun, “II. Dünya Savaşı Sonrası Türkiye'de Kültürel Değişimlere Yol Açan İç ve Dış Etkenler," Ankara, 2002 (basılmamış doktora tezi), s.110-118.

${ }^{3}$ Cumhuriyet Halk Fırkası Beşinci Büyük Kurultay Zabıtları, Ankara, Ulus Matbaası, 1939, s.25.

${ }^{4}$ İlhan Başgöz-Howard E.Wilson, Türkiye Cumhuriyetinde Eğitim ve Atatürk, Ankara, Dost Yay., 1968, s.82-83.

${ }^{5}$ Beyza Bilgin, Türkiye'de Din Eğitimi ve Liselerde ve Liselerde Din Dersleri, Ankara, Emel Matbaası, 1980, s.46. 
teşkilatlanması konusu görüşülürken, din adamı ve eski bir hoca olan Antalya Milletvekili Rasih Kaplan, köy çocuklarının din eğitimlerinin ihmal edilmemesi gerektiğini savunarak, din eğitimi için artık zamanın geldiğini belirtmiş ve köy okullarına din derslerinin konulmasını Milli Şef'ten rica etmiștir. Kütahya Milletvekili Besim Atalay ise, bu görüșü desteklemekle yetinmeyerek, din eğitimine yeniden başlanması konusunda bir takrir vermiştir. Sivas Milletvekili Abdurrahman Naci de bu takriri desteklemiştir. Bunun üzerine TBMM Başkanı Abdülhalik Renda, çoğunluk olmadığı gerekçesiyle çabucak oturumu kapatmıştır. Bu arada CHP Grup Başkan vekillerinden Hilmi Uran, Atalay'ın takririni geri almasını sağlamış ve konu bu şekilde kapatılmıştır ${ }^{6}$.

Din eğitimi konusu böylece ilk kez meclis gündemine getirilmiş ve sonuçsuz kalmıştır. Sonuçsuz kalmasına rağmen hem meclis gündemine ilk kez taşınması hem de CHP içinde bazı milletvekillerince desteklenmiş olması düşündürücüdür. Üstelik bu olay oldukça otoriter bir yönetimin benimsendiği ve mecliste, her tür istek ve tartışmaların yaşanmadığ dönemde olması bir bașka önemli noktadır. Bu olay CHP'deki kadro değişimini ortaya koyması ve daha sonraki yıllarda yaşanacak değişimlere işaret etmesi bakımından oldukça önemlidir. CHP içinde din eğitiminin devlet eliyle yapılmamasından kaygı duyan bir kesimin varlığı bu olayla su yüzüne çıkmıştır.

\section{Kuran Kurslart ve Diyanet İşleri Başkanlığı}

$\mathrm{Bu}$ dönemde hükümetin politikalarının yanı sıra Diyanet İșleri Başkanlığı'nın da daha aktif bir rol oynamaya başladığını eldeki belgelerden görmek mümkündür. Diyanet İşleri Başkanlığı bir yandan Kuran kurslarına devam eden öğrenci sayılarının arttırılması için çaba harcarken, diğer yandan imam ve hatiplerin sayı ve maaşlarının arttırılması için girişimlerde bulunmuştur. 1939'da Kuran kursu öğretmenlerine ortalama 13-14 öğrenci düşmesinden şikayet eden Diyanet İşleri Başkanı, bu sayının arttırılması için Kuran kursu hocalarının daha çok çalışmasını istemiştir ${ }^{7}$.

Ancak Diyanet İşleri Başkanlığı bununla da yetinmeyerek, Kuran kursları için ilk kez bir talimatname de hazırlamıştır. 2 Ağustos 1939'da Başbakanlığa yollanan yazının başında bu talimatnamenin gerekçesi açıklanmıştır. Diyanet İşleri Başkanı Rıfat Börekçi talimatnamenin gerekçesinde, öteden beri camilerde belli zamanlarda isteyenlere ve ehil kişiler tarafından verilen "ta'limi kuran" işinin şimdiye kadar bir talimatnamesi olmadığını ve bu nedenle Kuran kursu vereceklerin ellerine birer vesika vererek bu işi yürüttüklerini belirtmiştir. Kişilerin ibadetlerini doğru yapabilmelerinin yanı sıra kasaba ve köyler için imam, hatip ve müezzin ihtiyacına da cevap vermeye çalıştıklarını ifade eden Börekçi,

\footnotetext{
${ }^{6}$ Faik Ahmet Barutçu, Siyasi Hatıralar, C.I, Ankara, 21.Yüzyıl Yay., 2001, s.569.

${ }^{7}$ Başbakanlık Cumhuriyet Arşivi (B.C.A.) 051/ V $42 \quad 12.102 .26$.
} 
Kuran kurslarının planlı ve programlı esaslara bağlanması ihtiyacının gereğini vurgulamıştır ${ }^{8}$.

Başbakanlığa yollanan bu talimatnamede; 3 Mart 1924 tarihli yasanın toplumu din ibadete dair bütün konularda toplumu aydınlatma görevinin kendilerine verildiğini ileri sürerek, Kuran kursu açma yetkisinin kendilerinde olduğu ifade edilmiştir. Kuran kursu hocalarının Diyanetçe tayin olunacağı, Pazar ve bayramlar hariç her gün cami ve mescit gibi belirli ve herkese açık ve belirli saatlerde kurs verileceği ve kursa katılanların ilkokul tahsilini bitirmiş olmaları gerektiği belirtilmiştir. Bu talimatnamede Kuran öğreticilerinin yapmaları gerekenler de açıklanmıştır. Kuran öğreticilerin görevler arasında dikkati çeken ise, "Türkçe ezan ve ikametin düzgün bir şekilde okunmasını temin etmek" ifadesidir? .

Kuran kurslarıyla ilgili bu talimatname ile birlikte artık kurslar sistemli biçimde açılmaya ve sayıları arttırılmaya başlanmıştır. Bu talimatnamede belirtilenlerin uygulama sırasında aksamalara uğradığı Eğitim Bakanlığı'nın yazılarından anlaşılabilmektedir. Eğitim Bakanı Hasan Âli Yücel'in 27 Ocak 1940 tarihinde Başbakanlığa yolladığı yazı bu durumu açıkça ortaya koymaktadır. Yücel bu yazısında, İçişleri Bakanlığı'ndan aldığı bilgiye göre, Diyanet İşleri Başkanlığınca çeşitli yerlerde açtı̆̆ı "Kuran Öğretme Kursları"nın sayısının 49'u bulduğunu, bunların 28'inin Diyanet bütçesinden, 21'inin ise fahri öğretmenler tarafından idare edildiğini, gerek İçişleri ve gerekse valiliklerden aldıkları bilgilerle, sürekli artan bu kursların mevcut kanunlara aykırı faaliyette bulunduklarını ileri sürmüştür. Kuran öğretimiyle ilgili talimatnamenin Eğitim Bakanlığı'ndan geçirilmeden uygulanmış olmasından yakınan Yücel'e göre, bu düzenleme Tevhid-i Tedrisat (Öğretimin Birleştirilmesi) ve Maarif Teşkilatı Kanunu'nun hükümlerine aykırı olarak, Eğitim Bakanlığı'nın ruhsatı ve onayı olmadan dershane açılmasının emri vaki haline getirilmesinden duyduğu rahatsızlığı dile getirmektedir. Bu dershanelere kurs adının verilmesini de "kurs" yasanın tarifine uygun olmadığını vurgulayan Yücel, tüm bunlara rağmen Diyanet İşleri Başkanlığı'nın bu talimatnameye bile sadık olmadığını ifade etmiştir. Kuran öğretmenlerinin çoğunlukla ilkokulu bitirmemiş olanlara Arap harfleriyle öğretim yaptıklarını, bu konuda Arap harfleriyle yazılmış Türkçe alfabelerin kullanıldığını ve öğrencilerini az çok okumayı öğrenenlerden seçtiklerini belirten Yücel, Arap harflerinin 49 dershanede bu kadar teşvikle okutulmasından doğacak endişeye işaret etmektedir ${ }^{10}$.

Maarif Vekili Yücel, öncelikle Kuran kurslarının hali hazırdaki durumu ve işleyişiyle ilgili saptamayı yaptıktan sonra raporunda bakanlığın görüşlerine de yer vermiştir. Buna göre; Diyanet İşleri Başkanlığı'nın bakanlığın onayını almadan dershane açmasının yasaya aykırı olduğunu,

\footnotetext{
${ }^{8}$ B.C.A., Başbakanlık Muamelât Umum Müdürlügüu, 030/10 26. 151. 13., s.1-2.

${ }^{9}$ B.C.A., Başbakanlık Muamelât Umum Müdürlüğü, 030/10 26. 151. 13., s.3-4.

${ }^{10}$ B.C.A., 030/01 90. 559. 3., s.3-4.
} 
Diyanetten ödenek almayan 21 dershanenin hemen kapatılması veya açanlar hakkında soruşturma başlatılması, Kuranın Arap harfleriyle öğretilmeşinden vazgeçilmesini ve Türk harfleriyle yazılmış kuran tercümesi üzerinde öğretim yapılmasını, Kuran öğretme dershaneleri hakkındaki talimatnamenin incelenmesi için bakanlığına yollanmasını ve talimatname son şeklini alana kadar bu dershanelerde öğretime ara verilmesini ve dershanelerin denetiminin kendilerine verilmesi istenmiştir ${ }^{11}$.

Bu rapordan da anlaşıldığı gibi, Eğitim Bakanlığı, Kuran kurslarının mevcut durumundan büyük endişe duymaktadır. Esasen bu kurslar ilk açıldığı tarihten itibaren Eğitim Bakanlığı, Öğretimin Birleştirilmesi Yasasını gerekçe göstererek bu kursların kendilerine bağlanmasını istemiştir. Görünen o ki, Eğitim Bakanlığı, Diyanet İşleri Başkanlığı'na yeterince güven duymamaktadır. Devletin iki resmi kurumu arasındaki bu güvensizlik, yasaların farklı yorumu ve laiklik anlayışlarındaki farklılık dikkat çekicidir. Özellikle kurs sayısının her geçen gün artması ve Arapça eğitim Eğitim Bakanlığı'nın en çok üzerinde durduğu konu olmuştur.

Yücel'in yolladığı bu yazıya başbakanlığın bir türlü yanıt vermemesi de oldukça düşündürücüdür. Bu nedenle 6 Mart 1940'da yolladı̆̆ı yazıyı hatırlatan Yücel, bu konuda Başbakanlığın emirlerini beklediğini belirtme gereği duymuştur ${ }^{12}$. Ancak Başbakanlık bu yazıya da bir yanıt vermemesine rağmen, Eğitim Bakanı Yücel, 1srarla bu konunun takipçisi olmuştur. 13 A ğustos 1941'de bu kez ilk tahsil çağındaki çocukların Kuran Ö ğretme kurslarına alındığı, bu durumun çocukların zorunlu eğitim yapmalarına engel olacağını belirterek buna izin verilemeyeceğini vurgulamıştır ${ }^{13}$.

Eğitim Bakanı Yücel'in bu ısrarı sonucunda Başbakanlık Müsteşarı'nın imzasıyla Diyanet İşleri Başkanlığı'na bir yazı yollanarak, henüz ilk tahsilini bitirmemiş çocukların bu kurslara alınmamasının sağlanması istenmiştir ${ }^{14}$. Bunun üzerine Diyanet İ̧̧leri Başkan Vekili Ahmet Hamdi Aksekili, şimdiye resmi öğrenci kayıtlarında ilk tahsilini bitirmemiş olanlara rastlanmadığını ileri sürmüştür. Aksekili, cami ve mescit gibi herkese açık olan yerlerde öğretim yaptıkları için, okulları tatil olan öğrencilerin de bu kursları dinlemeye gelmiş olabileceğini ve bu konudaki hassasiyetlerini müftülüklere bildireceklerini belirtmiştir ${ }^{15}$.

Görüldüğü gibi, Eğitim Bakanı Hasan Âli Yücel'in "Kuran Öğretme Kursları" ile ilgili mücadelesi sonuçsuz kalmıştır. Yücel'in konuyu ısrarlı takibine rağmen, Başbakanlık bu kursların Eğitim Bakanlığı'nın denetimine verilmesini gerekli bulmamış ve Yücel'in eleştirilerine karşılık olarak da

\footnotetext{
"A.g.b., s.5.

${ }^{12}$ B.C.A., 030/01 90. 559. 3 ,

${ }^{13}$ B.C.A., 030/10 26. 151. 15

${ }^{14}$ A.g.b.

${ }^{15}$ A.g.b.
} 
sadece Diyanet İşleri Başkanlığı'nı uyarmakla yetinmiştir. Bundan başka bir önlem alma gereği duymamıştır. Üstelik bütün eğitim ve öğretim kurumları Eğitim Bakanlığı'na bağlıyken böyle bir kursun Diyanet İşleri tarafından yürütülmesinde sakınca görülmemiştir. Bu durum Atatürk dönemiyle başlamıştır, ancak kurs ve öğrenci sayıları az olduğundan pek dikkat çekmemiş olmalı ki, yeni bir düzenlemeye gidilme gereği duyulmamış olsa gerek.

İlk kuran kursları 1924 yılında açılmış ve 1937'e gelindiğinde toplam sayı 16 olmuştur. Bu kurslar, Diyanet İşleri Başkanlığı'na bağlı ve Latin harfleriyle öğretim yapmaları zorunlu kılınmıştı. Bu kurslardan mezun olanlar çoğu imam olarak atanmışlardır. Ancak 1940'dan sonra kursların sayısında belirgin bir artış göze çarpmaktadır. 1940-41'de kurs ve öğrenci sayısı 3-4 kat artmıştır. 1945'e gelindiğinde kurs sayısı 61'e, öğrenci sayısı ise, 8706 'a çıkmıştır ${ }^{16}$. Kuşkusuz bu durum Diyanet'in başarısını açıkça ortaya koymaktadır.

Diyanet İşleri Başkanlığı, Kuran kurslarının yanı sıra imam ve hatiplerin durumlarının iyileştirilmesi ve teşkilatın yeniden düzenlenmesiyle ilgili çalışmalara da girişmiştir. İnönü iktidarının daha ilk aylarında 5 Ocak 1939 'ta imam ücretlerinin arttırılmasıyla ilgili talebi Diyanet İşleri Başkanlığı, Başbakanlığa sunmuştur. Bu yazıda köy imamlarının maaşlarının azlığı nedeniyle görevlerini bıraktıkları belirtilerek, imamsız köyün uygun olmayacağını ve bu nedenle evvelce verilen paranın herhangi bir sebeple kesilmemesi istenmiştir ${ }^{17}$. Bunun üzerine Başbakanlık harekete geçerek Dahiliye Vekaleti'nden bilgi alınmış ve olağanüstü önlemler nedeniyle yapılan bu uygulamanın ekonomik durumu iyi olan köylerde düzeleceği ifade edilmiştî ${ }^{18}$. 1943 yılına gelindiğinde ise, Vaiz ve hocalara parasız giyim eşyası verilmesi hakkındaki yasaya rağmen bazı yerlerde verilen kumaşların geri alınmasından yakınılmıştır. Az maaşla hayat pahalılığından en çok acı çeken ama görevlerinde asla gevşeklik göstermeyen diye nitelenen vaiz ve hocalara uygulanan bu durumun yasalara aykırı olduğundan bir an evvel durdurulması istenmiştir ${ }^{19}$. Bu dönemdeki yazılarda genel olarak imam ve hatiplerin durumlarının iyileştirilmesi konusunda hassasiyetle duran Diyanet İşleri Başkanlığı, bu durumun düzeltilmesi için sıklıkla girişimlerde bulunmuştur. Kuşkusuz ekonomik zorluklar, bu kesime karşı özellikle benimsenmiş bir politika değildir. Savaş koşulları içinde özellikle sabit gelirliler en çok zor durumda kalan kesimler olmuştur. Savaş yılları içinde alınan olağanüstü önlemler enflasyonu, fiyat artışlarını, karaborsacılığı yeterince önleyemediğinden dar ve sabit gelirliler ve tabii Diyanet personeli de bu durumdan üzerine düşen payı kuşkusuz almıştır.

\footnotetext{
${ }^{16}$ Gotthard Jaschke, Yeni Türkiye'de İslamlık, Ankara, Bilgi Basımevi, 1972, s.75-76.

${ }^{17}$ B.C.A., Muamelat Umum Müdürlüğü, 030/10 192. 317. 11, s.5.

${ }^{18}$ B.C.A., Muamelat Umum Müdürlüğü, 030/10 192.317. 11, s.1-3.

${ }^{19}$ B.C.A., Muamelat Umum Müdürlüğü, 030/10 26. 151. 19.
} 
Diyanet İşleri Başkanlığı'nın bu dönemde yaptığı önemli çalışmalardan biri de yeni teşkilat kanununu hazırlamasıdır. Bu çalışmada en önemli olan konu, bu kanunun gerekçesinde yer almaktadır. Bu kanunun gerekçesi, teşkilatın ve kadroların mevcut durumunu ortaya koyduğu kadar dönemin genel yansımasını da teşkilatın bakışıyla gözler önüne serebilecek niteliktedir. Gerekçede, Diyanet İşleri Başkanlığı'nın görevini başarıyla yerine getirmesi ve iyi sonuçlar verebilmesi için aydın, donanımlı ve güçlü bir karaktere sahip din adamlarına gereksinim duyulduğu belirtilmiş ancak bu kişileri bulmanın zorluğuna dikkat çekilmiştir. Bunun yanı sıra "....bugün bir çok kasaba ve köylerde ezan okuyacak, namaz kıldıracak, ölüleri yıkayacak, Cuma hutbelerini okuyacak imam ve hatip hatta müezzin bile bulunmadığı..." ifade edilerek, mevcut imam ve hatiplerin her geçen gün azaldığı ve yerlerinin boşaldığı belirtilmektedir. Bundan önemlisinin müftü ve vaiz gibi din alimi bulunmasındaki güçlük olduğu, bu durumun başkanlı̆̆ı endişeye düşürdüğünü vurgulanarak, öncelikle din adamı yetiştirecek bir kaynak bulunmasının gerekliliği üzerinde durulmuştur ${ }^{20}$.

Gerekçede, Diyanet İşleri'nin birinci görevinin İslam dininin köylere kadar yüksek gerçeklerini yaymak ve halkın dini duygularını yükselterek, manevi alanda güçlü ve ahlaklı bireyler oluşturmak olarak açıklanmıştır. Bu görevi yerine getirmek ve "bu yoldaki derin ihtiyacı" çıkarlarımıza en uygun şekilde karşılayabilmek için din adamları, imam ve hatipler yetiştirmek gerektiği ifade edilmiştir. Bu kişilerin yetiştirilebilmesi için Diyanet İşlerine, çeşitli derecede mesleki kurum ve kurslar açabilme yetkisinin verilmesi istenmiştir. Tüm bu nedenlerle başta merkez kadronun genişletilmesi ve yeni memurlukların kurulmasının kararlaştırıldığı ve mevcut kadroya da zam istendiği belirtilmektedir ${ }^{21}$.

Bu kanun önerisinde Diyanet İşleri Başkanlığı'nın bütçesi neredeyse iki katına çıkarılmıştır. 14 Nisan 1942'de hazırlanan bu kanun tasarısı yasalaşmamıştır. Ancak Başkanlık, kanun gerekçesinde açıkladığı görüşlerle, bir anlamda mevcut uygulamaları önemli ölçüde eleştirmektedir. Din işlerini yürütecek yeterince kadronun olmamasının halkın ibadetini yerine getirmesine engel olduğunu ortaya koymakla, mevcut laiklik uygulamalarını da üstü kapalı biçimde suçlamaktadır. Çeşitli eğitim kurumlarını ve kurslarını açma iznini istemesi ise, ayrıca düşündürücü bir unsurdur. Çünkü mevcut Kuran kurslarını açma hakkının Diyanette olduğu göz önüne alınırsa, istenilen düzenlemelerin hem Öğretim Birliği Yasası'yla hem de laiklikle uyuşmadığı gözlenebilecektir. Bu dönemde kaç köyün imamsız kaldığı veya ibadetlerini yapamadığıyla ilgili bir kayıt mevcut değildir: Bu durumda Diyanet İ̧̧leri Başkanı'nın ortaya koyduğu tabloyu doğru kabul etmek de söz konusu olamaz. Şerafettin Yaltkaya'nın imzasıyla verilen bu kanun önerisi, ekonomik zorlukların en yoğun biçimde yaşandığı bir döneme denk geldiği

\footnotetext{
${ }^{20}$ B.C.A., Muamelat Umum Müdürlüğü, 030/ 10 26. 151. 16., s.3-4.

${ }^{21}$ A.g.e., s.4-5.
} 
göz önüne alınırsa böyle bir tasarının kabulü oldukça zor görünmektedir. Bu nedenle Diyanet İşleri Başkanlığı'nın bu istekleri kabul görmemiştir.

\section{Ibadet Yerleri}

Savaş yılları boyunca halkın ibadetlerini yerine getirme konusunda hassasiyetle durulmuştur. Laiklik uygulamalarına aykırı hareket edilmemesi konusunda ilk zamanlar idari birimler sıkı biçimde takip içinde olmuşlardır. Bunun en önemli örneklerinden biri Ankara Valisi Nevzat Tandoğan'ın camiler dışında toplu namaz kılınmasını engellemeye yönelik girişimidir. Ancak Tandoğan'ın bu girişimi Diyanet İşleri Başkanı'nın büyük tepkisini çekmiştir. Başkan Rıfat Börekçi, mevcut camilerin Ramazan aylarında yeterli olmadığını, bu nedenle cemaatle evlerinde namaz kılmak isteyenlere başvuruları üzerine izin verildiğini belirterek, başkanlığın resmi iznine rağmen valiliğin bu durumu engellemesinden duyduğu rahatsızlığı 20 Ekim 1939'da Başbakanlı'ğa bildirmiştir. Üstelik Yaltkaya'ya göre, Akköprü'de cami olmadığından buldukları boş bir handa toplu namaz kılınma iznini vermelerine rağmen, vilayetin burayı da kapattığını ileri sürmüştür. Cemaatle namaz kılmak için izne gerek olmadığını da vurgulayarak, bu konuda izin gerekirse tek yetkili kurumun kendi başkanlıkları olduğunu savunmuştur. Kendi izinlerine rağmen valiliğin cemaat olarak namaz kılınmasının engellenmesinin, namaz ve ibadet işlerine karışmak olarak nitelendirmiş ve bunun halkın duygularını rencide ettiğini belirtmiştir. Yaltkaya, vicdan özgürlüğü serbest, iman ve ibadetin her türlü tecavüzden masun olan ulusal ve laik bir hükümet idaresinde yaşamaktan gurur duyduğunu belirterek, vatandaşların din duygularıyla oynanmaması için gereğinin yapılmasını Başbakanlıktan istemiştir ${ }^{22}$.

Yaltkaya'nın bu ifadeleri okunduğunda vatandaşın namaz kılmasının engellendiği şeklinde bir izlenim ortaya çıkmaktadır. Ancak, bu konuda kesin bir yargıda bulunmadan önce Tandoğan'ın konuyla ilgili Başbakanlığa yolladığı rapora göz atmak gerekmektedir. Tandoğan, konuyla ilgili müftülüğün isteğinin uygun olmadığını daha önce bildirilmiş olduğunu, Akköprü'de İsviçre hanının bir odasında ve Altındağ'da bir kulübede ezan okutturulup namaz kılınmasının yasalara aykırı olduğunu, camilerden başka yer göstermenin vicdan özgürlüğünü kısıtladığını savunmuştur. Ankara'da halkın ibadetine yetecek derece cami ve mescit olduğunu vurgulayan Tandoğan, bu durumun mevcut yasal duruma aykırı olduğunu ve Diyanet İşleri Başkanlı̆̆ı'nın veya müftülüklerin ibadet yeri kurabilmeleriyle ilgili bir düzenleme bulunmadığını ve bu konunun mülki amirlerin yetkisinde bulunduğunu savunmuştur ${ }^{23}$.

Yaltkaya, ibadet yerlerinin belirleme yetkisinin Diyanet İşleri'nde olduğu belirtmesine rağmen mevcut yasal düzenlemeler, böyle bir izin

\footnotetext{
${ }^{22}$ B.C.A., Muamelat Umum Müdürlüğü, 030/10 26. 151. 14. S.5-6.

${ }^{23}$ A.g.b., s.1-3.
} 
düzenlemesiyle istenilen yerde toplu namaz kılınmasına izin vermemektedir. Cemaatın namaz kılabilmesi için camiler ve mescitler mevcuttur. Bunun yanı sıra eğer böyle bir durum serbest bırakılması durumunda yaygınlaşması da içten bile değildir. Laiklik ilkesiyle de pek bağdaşır gözükmeyen bu olay bir başka gerçeğe işaret etmektedir. Şöyle ki; İki resmi kurum arasında işbirliği ve ortak çalışma söz konusu olması gerekirken, daha önce Maarif Vekaleti'yle Diyanet İşleri arasında olduğu gibi, benzer biçimde valilikle de arasında bir güvensizlik söz konusudur.

İnönü döneminin laiklik politikalarıyla sıklıkla eleştiri konusu olan önemli bir konuya da burada değinmek istiyoruz. Bu dönemde cami ve mescit gibi ibadethanelerin askeriyeye verilerek buraların farklı amaçlarla kullanıldığı yönündeki iddialar zaman zaman belli çevreler tarafından eleştiri konusu edilmektedir. Öncelikle bir saptama yapılması gerekmektedir. 19391945 yılları içinde savaşa her an hazır olmak amacıyla ordudaki asker sayısı yaklaşık dört kat birden arttırılmış ve asker sayısı bir milyona çıkarılmıştır. Savaşın her an Türkiye'ye sıçrama tehlikesine karşı hazırlıklı olma amacıyla alınan bu önlem, öncelikle hükümeti önemli bir ekonomik sorunla baş başa bırakmıştır. Bunun yanı sıra asker sayısının artması barınma problemini de beraberinde getirmiştir. Barınma sorununu gidermek amacıyla bir çok olağanüstü önlem alınmıştır. Bu önlemlerden biri de öncelikli olarak kullanılmayan, ihtiyaç ve kadro dışı camiler ordunun kullanımına verilmiştir ${ }^{24}$. Sadece cami ve mescidler ordu emrine verilmemiştir, aynı anlayış çerçevesinde kullanılmayan kilise ve diğer ibadethaneler de ordu emrine verilmiştir ${ }^{25}$. Ancak bu durumdan tarihi kıymete haiz bulunan camiler istisna tutulmuştur ${ }^{26}$.

Tüm bu uygulamaların halkın tepkisini çekmediğini söylemek söz konusu değildir. Ancak bunun katı bir laiklik politikasından kaynaklandığını veya dine zarar verme amacı taşıdığını ileri sürmek haksız bir değerlendirme sayılmalıdır. Zaten dönemin laiklik uygulamalarına bir bütün olarak bakıldığında da bunu söylemek oldukça güçtür. Ancak savaş ortamının yarattığı olağanüstü bir önlem olduğu ve herhangi bir art niyetin söz konusu olmadığı değerlendirmesi daha doğru bir yaklaşım olsa gerek.

Diyanet İşleri Başkanı Yaltkaya, halkevlerinde oynanan bazı oyunların da din adamlarını kötüleyici içerikler taşıdığını ve bundan duyduğu rahatsızlığı dile getirmiştir. Bunlardan birisi, Çankırı Halkevi'nde oynanan bir oyunda köylünün cübbeli, sarıklı bir hocanın yanında oturmak istemeyip onun kötüleyen sözler söylenmesidir. Yaltkaya böyle bir oyunun sergilenmesini eleştirerek, cübbe ve sarığın devlet tarafından verilen resmi

\footnotetext{
${ }^{24}$ B.C.A., Başvekalet Umum Müdürlüğü, 030/10 192. 318. 6.

${ }^{25}$ B.C.A., Başvekalet Umum Müdürlüğü, 030/10 192.318. 15.

${ }^{26}$ B.C.A., Başvekalet Umum Müdürlüğü, 030/10 192.317.9.
} 
bir üniforma olduğunu, ona kimsenin hakaret edemeyeceğini ve din adamlarının saygınlığına zarar verilemeyeceğini sert bir dille ifade etmiştir ${ }^{27}$.

Yaltaya'nın bu ifadeleri bir iki olayla sınırlı olup geneli kapsayan bir nitelik taşımamaktadır. Yazıdan anlaşıldı̆̆ 1 kadarıyla böyle bir duruma hükümetin de izin vermeyeceği savunulmaktadır. Devletin resmi politikasında, tüm din adamları değil, dini çıkarları için araç olarak kullanan ve halkın cehaletinden çıkar sağlayan sahte din adamları her zaman devrime zararlı insanlar olarak görülmüştür. Bu da çoğu kez sarık ve cübbeyle sembolize edilmiştir. Ancak bu durum oyunun geneliyle ortaya konulabilecek bir konudur. Oyunun geneliyle ilgili bir bilgi söz konusu olmadığından, bu konuda tam bir değerlendirme yapmak söz konusu olamamaktadır.

\section{İlk İslami Muhalefet}

Savaş yıllarında hükümetin laiklik uygulamaları da inişli çıkışlı bir manzara arz etmektedir. Bir yandan köy ilkokullarından din dersleri kaldırılırken hemen sonrasında, dinin yeniden toplum ve devlet yaşamında canlanacağına dair söylentilerini bir ölçüde doğrulanırcasına askeri imamların orduya dönmesi sağlanmıştır ${ }^{28}$. Ancak, değişim süreci daha ileri götürülmemiştir.

Bunun yanı sıra dönemin İslami muhalefetinin ilk açık belirtisi de bu dönemde kendini ortaya koymuştur. Kuşkusuz uzun yıllar yer altında yaşamak zorunda kalan siyasal ideoloji olarak İslam, bu yıllar içinde kendini basın hayatıyla var etmeğe çalışmıştır. Ancak şunu belirtmek gerekir ki, 1940 'l 1 y 1 llara girerken, toplumda Kemalist ideolojiye veya uygulamalara karşı belirgin ve etkili bir tavır alma söz konusu değildir. Ancak yine de İslamcı hareket, varlığını yer altında sürdürürken bu dönemle birlikte "cılız" da olsa bazı çıkışlarla varlığını hissettirmeye çalışmıştır.

Bunlar içinde 1939'da cumhuriyetin ilk yasal İslami muhalefet organı sayılabilecek "Hareket" dergisi yayın hayatına girmiştir. Hareket dergisi, eski Sebilü'r-reşat'ı çıkaranlar tarafından yayınlanmaya başlamıştır. Görüldüğü kadarıyla bu dergi, toplumdaki dinci ve muhafazakar kesimleri bir araya getirmeyi başarmış ve onların sesi olmuştur ${ }^{29}$. Devletin laiklik politikasına ilk karşı çıkışlarına ise, 1940 yılında rastlıyoruz. Avrupalı Doğu bilimcilerden kurulu uluslararası bir heyet tarafından yayınlanan "Encyclopaedia of İslam” adlı büyük ortak eser, 1939 yılında Milli Eğitim Bakanlı̆̆ tarafından Türkçeye çevirip yayınlamaya karar verilmişti. Ancak bu tam bir çeviri olmayacaktı; eskimiş olan yazılar Türk bilim adamları tarafından gözden geçirilerek yeniden yazılacak ve eksik görülen kısımlar ise tamamlanacaktı. Ancak tüm bunlara rağmen ilk baskısındaki bilimsel

\footnotetext{
${ }^{27}$ B.C.A., Başvekalet Umum Müdürlüğü, 030/10 26. 151. 17.

${ }^{28}$ Bernard Lewis, Modern Türkiye'nin Doğuşu, Ankara, TTK Yay., 1991, s.412.

${ }^{29}$ Gencay Şaylan, Türkiye'de İslameı Siyaset, II.B., Ankara, V Yay., 1992, s.92-93.
} 
düşünce çerçevesi içerisinde kalınacaktı. Bunun üzerine II.Meşrutiyet dönemindeki sebilü'r-reşat dergisinin yayıncısı olan ve Eşref Edip ve Hareket dergisinde de yer alan dindar nitelikli bir grup, kabul edilen bu projeye sert biçimde muhalefet etmiştir. Encyclopaedia of İslam'ın Hıristiyan misyonerleri tarafından hazırlandığını savunan İslamcı muhalefet, bu ansiklopedinin misyonerlerin çalışmalarına yardımcı olmak ve İslam dininin temellerini yıkma amacı taşıdığını ileri sürmüştür. İslama karşı ve onu yıkma macı taşıyan bu projeyi desteklediği için de, Milli Eğitim Bakanlığı'nı başta kendi çıkardıkları Hareket dergisi olmak üzere diğer basın organlarında yazdıkları makalelerle eleștirmişlerdir. Hatta daha da ileri giderek "Türk-İslam Ansiklopedisi" adıyla tamamen Müslümanların bakış açısıyla yazılan yazıların yer aldığı kendi ansiklopedilerini yayınlamaya başlamışlardır. Türk-İslam Ansiklopedisi'nin her fasikülüne, Eğitim Bakanlığı'nın çıkardığı ansiklopedinin çıkan fasikülleri hakkında şiddetli ve hatta küfür sayılabilecek nitelikte eleştirel yazıları içeren bir magazin de eklemişlerdir ${ }^{30}$.

Hareket Dergisi'ni Büyük Doğu takip etmiştir. Savaş yıllarının ortalarında yayın hayatına başlayan bu dergi, yaklaşık on aylık kapatma cezasıyla cezalandırılmıştır ${ }^{31}$.

Savaş yılları içinde hükümet büyük baskı altında tutmasına rağmen, bu görüşlere karşı etkili biçimde önlemler alındığı söylenemez. Öyle sanıyoruz $\mathrm{ki}$, bu dönemde özellikle dış politik gelişmeler basının baskı altında tutulmasının en önemli gerekçesi olmuştur. Hükümet daha çok, kendi dış politika çizgisi içinde basını tutmaya çalışmış, bu çizgi dışına çıkanları ise, büyük ölçüde cezalandırılmıştır. Hareket dergisi yazarlarının yazılarına karşı önemli bir yaptırım gözükmemektedir.

Ancak din ile ilgili basılan kitap ve dergiler ise, Matbuat Umum Müdürlüğü tarafından sıkıca takip edildiği görülmektedir. Basılan kitap ve broşürlerden "zararlı" görülenler Bakanlar Kurulu kararlarıyla satılması yasaklanmış veya toplatılmıştı̂ ${ }^{32}$.

\section{Arapça Ezan Yasağı}

Laiklik uygulamaları konusunda düzenli ve sistemli sayılabilecek bir durum bu dönem için söz konusu olmadığının bir başka göstergelerinden biri de Arapça ezan okunması yasağının yasalara bağlanmasıdır. Atatürk döneminde 1932'de başlayan Türkçe ezan okunması uygulaması, bir tamimle düzenlenmiş ve yasayla Arapça ezan yasaklanmamıştır. İnönü döneminde ise, bu uygulamada bir boşluk görülerek 2 Haziran 1941'de

${ }^{30}$ Lewis, s.412-413.

${ }^{31}$ B.C.A., 030. 18. 1.2./ 107. 107. 11. Büyük Doğu, 8 Mayıs 1944 'de kapatılmış 30 Mart 1945 'te yeniden yayın yapmasına izin verilmiştir.

${ }^{32}$ B.C.A., 030. 18. 1.2./92 88. 14. ; 030. 18. 1.2/ 85. 97. 15; 030. 18. 1.2./ 85.97.17; 051. V33 4. 36. 19. 
kabul edilen 4055 sayılı yasayla, Türk Ceza Yasası'nın 526. maddesinde değişikliğe gidilmiş ve Arapça ezan okuma yasağı getirilmiştir. Bu yasaya uymayıp Arapça ezan okuyanlara üç aya kadar hapis ve para cezası öngörülmüştür. Bu yasanın gerekçesinde ise, 1932'de çıkarılan ezanın Türkçe okunmasıyla ilgili tamime uymayanlar hakkında yasal işlem yapılmasına rağmen, yasal bir yaptırım olmamasından dolayı caydırıcı olmadığı ileri sürülmektedir. Yapılan bu değişiklikle bu konudaki yasal boşluğun giderilmesi amaçlandığı ifade edilmektedir ${ }^{33}$.

Kuşkusuz bu uygulamanın temelinde, bu dönemde de hala Arapça ezan okuma konusunda yaşanan gelişmelerin olduğu gözlenebilmektedir. Bununla birlikte tüm bu sorunlarda hükümetin laiklik konusundaki uygulamalarının gelgitlerle dolu olması böyle gelişmelerin yaşanmasında etkili olmuş olabilir. Atatürk'ün ölümünden sonra çıkan söylentilerin de payı olduğu kuşkusuzdur.

\section{CHP Programinda Laiklik İlkesi}

Atatürk'ün ölümünden sonra ilk CHP Kurultayı 1939'da toplanmıştır. Beşinci Kurultay'da kabul edilen yeni programda laiklik ilkesinin tanımı, 1935 'te kabul edilen programın aynısı değişiklik yapılmadan kabul edilmiştir.

Cumhuriyet Halk Fırkası'nın Altıncı Büyük Kurultayı'nda son yaşanan gelişmeler ışı̆̆ında laiklik ilkesinin tanımı da değişikliğe uğramış, daha doğrusu eklemeler yapılmıştır. Yeni ekleme ise öncelikle vicdan özgürlüğü ile ilgilidir; "Din telâkkisi vicdani olduğundan her türlü taarruzdan ve müdahaleden masundur" cümlesi 1943'teki altıncı kurultayda kabul edilen programa eklenmiştir. Buna göre laiklik tanımı biraz daha genişletilmiştir. Bunun yanı sıra, ulusal dil ve kültürün diyanet yoluyla yabancı dil ve kültürlerin etkilerinden korunmasının Türk ulusunun geleceği için zorunlu sayıldığı da belirtilmiştir ${ }^{34}$. Laiklik ilkesiyle ilgili özellikle birinci değişiklik önem taşımakta ve laikliğin vicdan özgürlüğünü içerdiği diğer programlarda açıkça yer almamasına rağmen bu programda yer bulmuştur.

\section{Sonuç}

Atatürk'ün ölümü hiç kuşkusuz Türkiye ve Türk Devrimi'nin geleceğe açısından önemli bir dönüm noktası olmuştur. Atatürk'ün öldüğü yıllarda hızla esen savaş rüzgarları Türkiye'yi içine almıştır. Türkiye savaşa girmemiş olmasına rağmen, ekonomik, siyasal ve sosyal yaşamda savaşın etkilerini derin biçimde hissetmiştir.

${ }^{33}$ Rıfkı Salim Burçak, On Yılın Anıları, Ankara, Nurol Matbaacılık, 1998, s.55-56; Düstur, Üçüncü Tertip, C.22, Ankara, Devlet Matbaası, 1941, s.1298.

${ }^{34}$ CHP Program ve Nizamnamesi, Ankara, Zerbamat Matbaası, 1943, s 5. 
Savaş yıllarının laiklik uygulamalarına genel olarak bakıldığında, planlı ve sistemli bir laiklik politikasının olmadığı ilk bakışta göze çarpmaktadır. Dönem boyunca bir yandan laiklik ilkesini tamamlayıcı nitelikte girişimlerde bulunulurken diğer yandan laiklikten gerileme sayılabilecek bazı uygulama

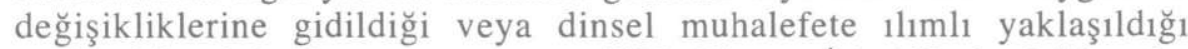
gözlenebilecektir. Bunun yanı sıra özellikle Diyanet İşleri Başkanlığı'nın bu dönemdeki etkinliğinin artışı da dikkati çeken olaylarından biridir. Hükümetlerin, bu faaliyetler karşısında engelleyici bir yaklaşım sergilememeleri veya olumsuz yaklaşmamaları bu faaliyetlerden rahatsızlık duymadıklarını göstermektedir. Özellikle Kuran kurslarının ve öğrenci sayısının gittikçe artması ve Arap harfleriyle öğretim yapılması konusunda Eğitim Bakanlığı'nın ortaya koyduğu endişe ve görüşlerine katılmamaları da konuya ılımlı yaklaştıklarının bir başka kanıtıdır.

Köy ilkokullardaki din derslerinin kaldırılması ve Arapça ezan okumaya ceza yaptırımının getirilmesi laiklik ilkesini tamamlayıcı uygulamalar olarak görülebilir kuşkusuz. Ancak gerek kuran kursları konusu gerekse din eğitiminin ilk olarak mecliste tartışılmaya başlanılması da gelecekteki değişimlerin ilk işaretleri olarak karşımıza çıkmaktadır. İslamcı muhalefetin bu dönemde kendini ortaya koyması da nedensiz olmasa gerek. Savaş yıllarının basına koyduğu ağır baskıya rağmen İslami ideolojiye sahip kesimlerin uzun zaman yer altında kaldıktan sonra ortaya çıkmaları ve uygulamalara muhalefet edebilmeleri, zaman zaman sağ ve sol düşünceye yapılan baskılardan bu kesimlerin fazla etkilenmediğinin göstergesi sayllabilir.

İsmet İnönü'nün Cumhurbaşkanı seçilmesiyle birlikte devlet yönetiminde ve CHP kadrolarında başlattığı değişim hareketi, genel olarak dönem içinde izlenen politikaları etkilemiştir. Ancak bu değişimin parti ve devlet siyasetindeki derin etkileri 1945 'ten sonra görülecektir. Bunun en güzel kanıtı 1945 yılının ortalarında CHP milletvekillerinin düşünce yapılarının karşılaştııılmasıyla ortaya çıkabilecektir. Bu dönemden sonra yaşanan siyasal olaylar ve partideki gelişmeler incelendiğinde CHP'de birbirinden oldukça farklı hatta zit denebilecek görüşlere sahip milletvekillerinin parti içinde yer aldığını görmek mümkündür. İnönü'nün toplumsal bütünlüğü sağlamaya yönelik olarak devrimlere ve Atatürk'e karşı olanları parti ve devlet yönetimine sokma girişimleri, devrimlerin uygulamalarında da etkisini gittikçe artan biçimde hissettirecektir.

Savaş yıllarında laiklik uygulamalarında yaşanan sistemsizlik savaş yılları içinde büyük bir değişimle kendini ortaya koymamıştır. Ancak, bu dönemde başlayan ve biriken konular, çok partili yaşama geçtikten hemen sonra toplumsal muhalefetle de birleşerek, laiklikten verilen büyük ödünler olarak karşımıza çıkacaktır. Çok partili yaşama geçişten sonra ilk tartışmaya açılan ilkenin laiklik olması ve devrimlerden ilk ödünlerin de bu alanda verilmesi basit bir tesadüf olarak algılanamaz. Gerek daha önce söz ettiğimiz kadro değişimi gerekse belirli bir laiklik politikasının söz konusu olmaması, 
bu değişim sürecini kolaylaştıran önemli etkenler olmuştur. Çok partili yaşamda laiklik uygulamalarında yaşanan değişimlerin ilk işaretlerinin, Atatürk'ün ölümünden sonra hemen sonraki süreçte verildiğini belirtmek kuşkusuz yanlış bir değerlendirme sayılamaz. Özellikle çok partili yaşama geçişle birlikte laiklikle ilgili yaşanan değişimler ve bu konudaki görüşler, bu düşünceyi doğrular niteliktedir. 